\title{
REVEALING A MARITIME CULTURAL LANDSCAPE OF HONG KONG: THE SAI KUNG CASE STUDY
}

\author{
Bill Jeffery* \\ University of Guam, Unibetsedåt Guåhan, College of Liberal Arts and Social \\ Sciences, Humanities, UOG Station, Mangilao, Guam 96913, USA \\ E-mail: jefferyw@triton.uog.edu \\ Joyce Ho-ching Kam $^{* *}$ \\ University of Hamburg, Asien-Afrika-Institut, Edmund-Siemers-Allee 1, \\ 20146 Hamburg, Germany \\ E-mail:me@doskoiorange.com
}

Published online: 30 July 2021

To cite this article: Jeffery, B. and Kam, J. H-c. 2021. Revealing a maritime cultural landscape of Hong Kong: The Sai Kung case study. International Journal of Asia Pacific Studies 17 (2): 107-133. https://doi.org/10.21315/ijaps2021.17.2.5

To link to this article: https://doi.org/10.21315/ijaps2021.17.2.5

\begin{abstract}
Hong Kong island is located in Southern China at the mouth of the Pearl River. Its coastal location down river from the significant port-city of Guangzhou (formerly Canton), is strategically located in the trade route known as the Maritime Silk Road, the 2,000-year-old trade between China, Southeast Asia, India and Arabia. It was because of this trade that the waters and islands at the Pearl River mouth were frequented by many nations, and where the Portuguese had their port-city, Macau from 1557, and the British were based on Hong Kong island from 1842. Over the next 60 years, the British leased further surrounding territories and the arrangement eventually led to the establishment of the Hong Kong Special Administrative Region, hereafter called the Hong Kong region. A significant maritime cultural landscape was built up, which included sites from earlier periods. An example of this maritime cultural landscape can be seen in the Sai Kung (eastern) district of the Hong Kong region. Many ships travelled along this coastline between the northern China ports and Guangzhou, and a number of coastal facilities were established. Beginning in 2009, a group of Hong Kong residents (Hong Kong Underwater Heritage Group) implemented a series of maritime archaeological projects in the Sai Kung district
\end{abstract}


in collaboration with the Hong Kong Maritime Museum (HKMM). The results of this work can be seen in three maritime archaeology survey and excavation projects implemented from 2014 to 2017, including the discovery of a 1,000-yearold underwater cultural heritage (UCH) site. They complement the many coastal cultural heritage in the Sai Kung district to reveal its maritime cultural landscape.

Keywords: Maritime cultural heritage, archaeology, shipwreck

\section{INTRODUCTION}

Few expect Hong Kong, a global financial hub, to have a rich trove of maritime cultural heritage. Yet in fact, traces of regional maritime activities can still be found upon close examination. The Sai Kung district was selected as a case study of the maritime cultural landscape in Hong Kong for a number of reasons. Its coastal region contains a significant number and variety of cultural heritage sites, from Palaeolithic sites to rock engravings, forts and shipwrecks. Together with the still active use of the Sai Kung coastline and adjacent ocean by boat dwellers and fishers, and the various ports they created and maintained, the Sai Kung district is an excellent representation of the maritime cultural landscape for much of Hong Kong, which has now unfortunately disappeared in many regions through massive coastal reclamation and development. It is also a coastal region much visited by Hong Kong scuba divers, who are known to have discovered underwater cultural heritage $(\mathrm{UCH})$ sites, providing an opportunity to further develop an inclusive community approach to maritime archaeology.

From about the Tang Dynasty (618-907 CE), the waters around Hong Kong were visited by Arab, Indian and Persian merchants keen to trade with China. The Portuguese later settled in Macau $-60 \mathrm{~km}$ across the other side of the Pearl River mouth from Hong Kong - since 1557, and Guangzhou - located about $110 \mathrm{~km}$ up the Pearl River-was made the only city for foreign trade since 1757 until the end of the first Opium War in 1842. As a result of the war, Hong Kong was ceded to the British through the Treaty of Nanking and soon became a prominent entrepot for the region. Many Chinese vessels voyaged from northern Chinese ports, along the China coast that included the Sai Kung district.

The Sai Kung district also shows clear evidence of much earlier coastal activity. A Palaeolithic site at Wong Tei Tung (dated between $7,700-2,200$ years old) indicates the coast was inhabited from the early 
Neolithic (Lu 2007; Zhang and $\mathrm{Ng}$ 2010) (as shown in Figure 1). Later coastal and marine exploitation activities such as pearl fishing, salt farming and lime smelting have also left tangible cultural heritage remains. While the district has not been spared from coastal development, but not to the extent as elsewhere, the maritime cultural landscape and the associated living heritage is largely authentic and worthy of revealing before it is also lost in this rapidly changing world.

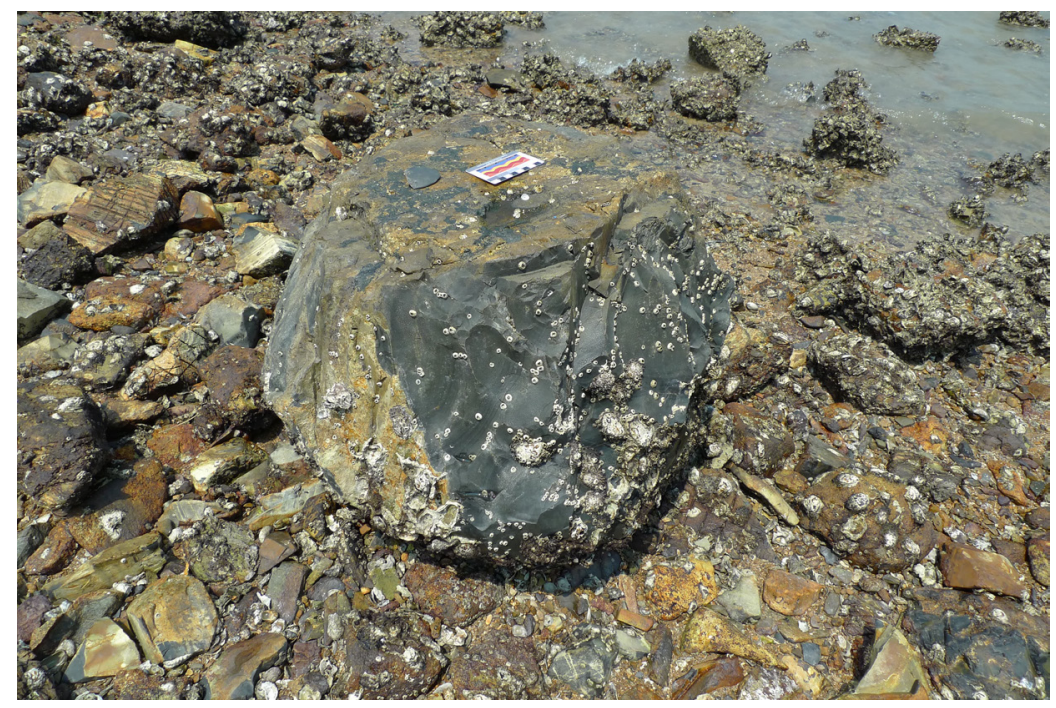

Figure 1: A one-metre diameter lithic core at Wong Tei Tung was located in two metres of water when first observed in 2009 (photo by Bill Jeffery, 2014).

Little maritime archaeology has been carried out in Hong Kong waters that can expand on this maritime cultural landscape, but it is well understood that $\mathrm{UCH}$ sites have the potential to reveal aspects not found in other forms of the cultural landscape. The sites and artefacts can help to reveal a timetable for their deposition; they can provide information about sea-routes; they can also be connected to other cultural landscape features, inland waterways and centres of manufacture of the trade goods as well as reveal socio-cultural and cognitive aspects that can lead to a more holistic understanding of the cultural landscape (Westerdahl 1992). The only ancient shipwreck found in Hong Kong, dated from the Ming Dynasty (1368-1644), called the Sha Tsui wreck, is located in the Sai Kung district, found when High Island Bay was reclaimed and turned into a reservoir.

Beginning in 2009, the HKUHG (Hong Kong Underwater Heritage Group) began to document Hong Kong's maritime cultural landscape in the Sai Kung district. This led to three major projects being carried out from 
2014 to 2017 at a site off Town Island, and two other sites at High Island and Basalt Island. The HKUHG maritime archaeology projects, in collaboration with the Hong Kong Maritime Museum (HKMM), are confirming aspects of Hong Kong's maritime history in addition to revealing a maritime cultural landscape that has but disappeared in much of the Hong Kong region.

\section{DEVELOPMENT OF MARITIME ARCHAEOLOGY IN HONG KONG}

The Hong Kong government funded a preliminary assessment of UCH sites in its waters in 1998, which identified 48 shipwrecks and 22 were identified as being of historical interest (AMO 2004; Draper-Ali 1998). Prior to 1998, any site discoveries were the result of accidental discovery and the Sha Tsui wreck was one of these discoveries. From 1998, the Environmental Impact Assessment (EIA) Ordinance process kicked-in. In 1999, the Underwater Archaeology Centre of the Museum of Chinese History implemented underwater archaeological investigations off Penny's Bay - where the terrestrial archaeology recovered about 26,000 Chinese and Southeast Asian ceramics from the late 15th to early 16th century (AMO 2004; Lam 1992; Wong 2015). About 150 areas of seabed in Hong Kong have been investigated as part of the EIA process, which can include using geophysical surveys and historical research, although little has been found, with the exception of HMS Tamar shipwreck (Heaver et al. 2015). One reason for this is that the seabed developments that trigger the EIA process do not always take place in areas conducive for the presence of UCH sites.

In 2001, the Hong Kong Underwater Archaeological Association financially supported China's Underwater Archaeology Centre to resume the investigation of the Nanhai No.1 shipwreck, which was recovered in 2007 and is located in the Guangdong Maritime Silk Road Museum in Yangjiang, China (China Daily 2007). After the UNESCO Convention on the Protection of Underwater Cultural Heritage came into force in 2001, the AMO (Antiquities and Monuments Office) facilitated a workshop for the Asia-Pacific region in 2003. Over 100 underwater archaeologists from this region came together in Hong Kong to discuss the many issues and benefits in ratifying the convention (Prott 2006). 


\section{MARITIME CULTURAL HERITAGE IN SAI KUNG AND SURROUNDING AREAS}

AMO of the Leisure and Cultural Services Department is the government agency responsible for the preservation, protection and promotion of the archaeological and built heritage in Hong Kong. They use two main pieces of legislation as providing a framework for this work: Antiquities and Monuments Ordinance (AM Ordinance) and the EIA Ordinance. Surveys have been undertaken to identify the heritage of Hong Kong, beginning in the 1980s with archaeological site surveys, followed by built heritage surveys from the 1990s, and intangible cultural heritage (living heritage) surveys from 2009 (Meacham 2008). The AMO provides a list of 208 Sites of Archaeological Interest (AMO 2012). Some of the listed coastal archaeological sites and monuments of interest in the Sai Kung district include (as shown in Figure 2):

1. Kau Sai Chau Rock Carving.

2. Joss House Bay rock inscriptions (dated 1274, these are the oldest dated inscriptions in Hong Kong).

3. Joss House Bay Tin Hau Temple, the oldest and largest in Hong Kong, dated 1266.

4. Rock carving on Tung Lung Chau.

5. Rock carvings at Lung Ha Wan.

6. Chinese Customs Station from the time of the Opium Trade at Fat Tau Chau, 1868-1899.

7. Leung Shuen Wan, a former Chinese Naval outpost and Market Centre for the area. Contains a Tin Hau temple, from where fishers perform an annual boat parade for the Sea Goddess (Chan 2006).

8. On Kau Sai Chau, a temple dedicated to Hung Shing Kung, a Tang Dynasty official who watched over in particular the boats and their crew, was also used as a schoolroom (Ward 1985: 31).

9. Tung Lung Fort, a Chinese fort built about 1720, and a declared monument under the AM Ordinance.

10. Sai Wan Archaeological Site, containing prehistoric coarse pottery and pottery from the Song dynasty. 

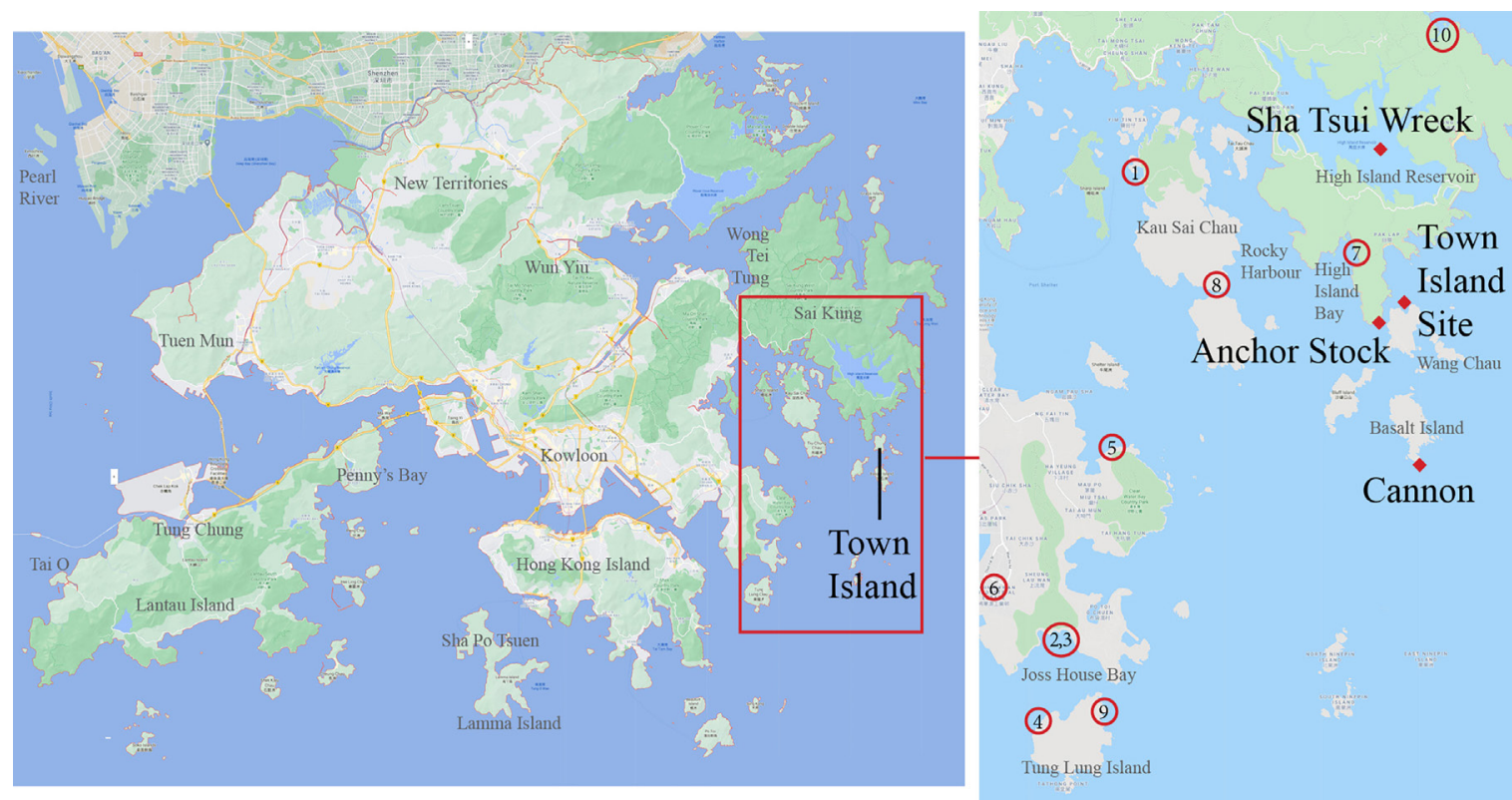

Figure 2: Map of Hong Kong (left) with an enlarged map of Town Island and the surrounding sites of archaeological interest (drawn by Joyce Kam using Google Maps).

These coastal sites reflect the activities of coastal settlements, fishing industry and military operations, and shall be interpreted in conjunction with the Sha Tsui wreck to get a more holistic picture of the maritime cultural landscape of Sai Kung. Although souvenir hunters disturbed this wreck site, archaeological surveys and excavations were conducted of the vessel and cargo remains in late May 1974 (Frost 1974: 23-27). The site spread out over an area of about $40 \mathrm{~m}$, and consisted of timber planking from the vessel's hull, the largest plank measuring 22 feet $(6.7 \mathrm{~m})$, iron and wooden fastenings, part of a stove made of red clay, pieces of broken brick, fragments of glass (assumed to be from a lamp), and about 1,000 earthenware and ceramic sherds (Ho and Ng 1974: 28-33). A boat builder from Sau Kee shipyard in Apli Chau considered the boat to be have been 70 to 80 feet in length $(21$ to $24 \mathrm{~m})$ and 16 feet in breadth $(4.8 \mathrm{~m})$ (Ho and $\mathrm{Ng}$ 1974: 28). The pottery is the most interesting being a variety of Thai Sawankhalok wares from the 14th century; Chinese Song wares from Kiangsi Province; Celadon sherds of unknown origin; Chinese blue and white from the Ming Dynasty; softer body sherds with stamped patterns from the simple corded pattern to the more sophisticated fish pattern and which resemble pottery from prehistoric sites in Hong Kong (Ho and $\mathrm{Ng}$ 1974: 31-32). It stands as a testimony to the international maritime connections of Sai Kung. 
Another important archaeological site is the Wun Yiu porcelain kilns, located in the Tai Po district ( $23 \mathrm{~km}$ northwest of Town Island), which was in operation from 1368 to 1932 . The kilns, used by multiple manufacturers with over 300 workers in employment at their peak, produced blue and white porcelain with a variety of decorative designs such as animals and plants, scenery and landscapes, characters, poems, and words with auspicious meaning and patterns.

\section{HISTORICAL BACKGROUND}

Information about Sai Kung, its environment and the people utilising the coast and sea, provide an important context for the archaeological sites discussed later in this article. Sai Kung is a predominantly mountainous region with limited flat arable land. It was noted in the 1688 Xin'an Xianzhi, also known as San On County Gazetteer, that the county was made up of high mountains and lofty peaks, which emerged from the shores of the deep sea (Hase 2003: 3). The documented maritime activities in the area which encompasses Town Island began with pearl fishing over 1,100 years ago.

One of the first Chinese maps of the area is Guangdong Yanhai Tu (Coastal Map of Guangdong) published in Yue Da $J i$ (General Record of Guangdong) by Guo Fei in 1595 (as shown in Figure 3).

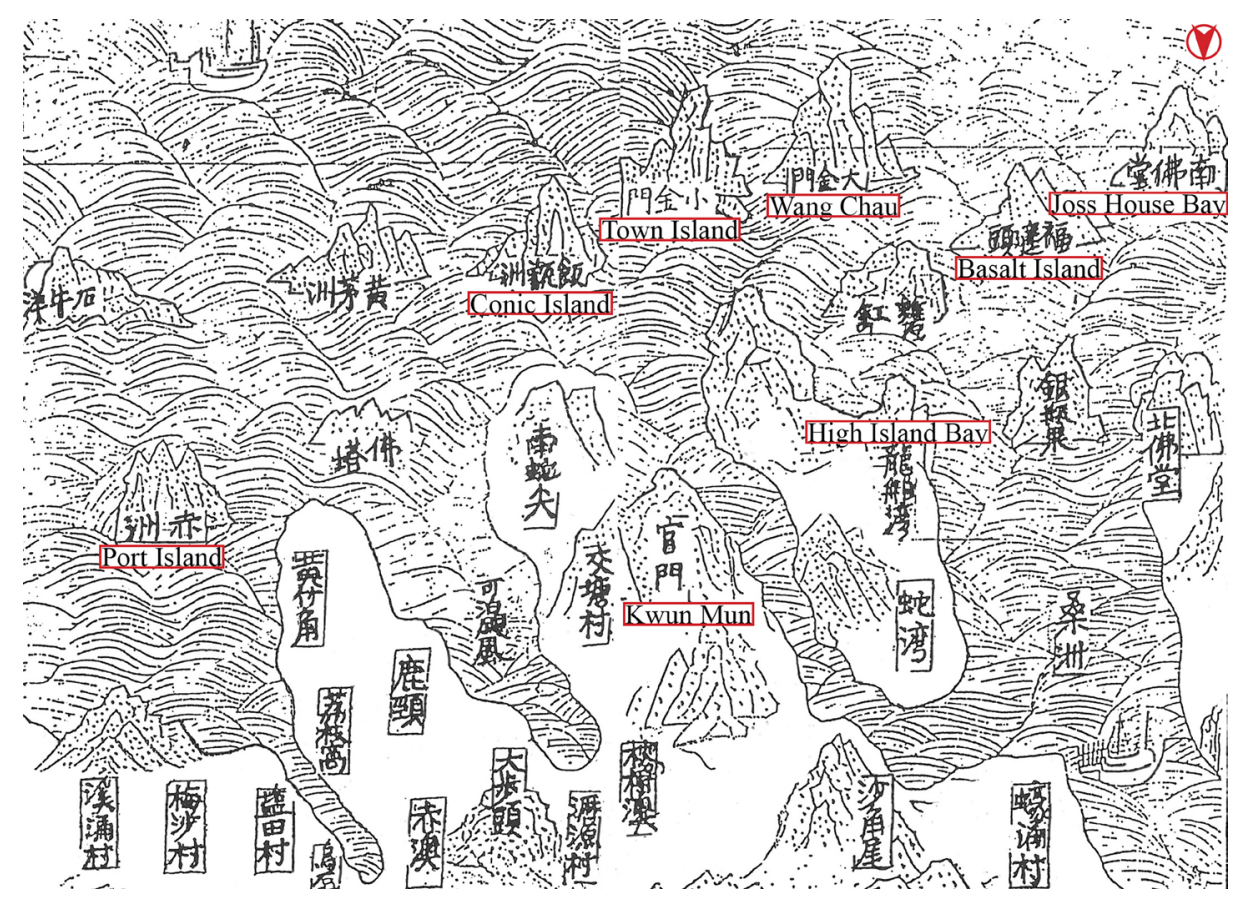

Figure 3: Area of Sai Kung on coastal map of Guangdong. Source: Guo (1595) 
This map denotes Town Island as "small gold door" and Wang Chau as "big gold door", which can be reached through the Kwun Mun Channel, literally means "official door", It is believed that the channel was used by government ships, hence the name. The island pair served as a landmark for trade ships to enter High Island Bay, a typhoon shelter. Such function is reflected in its Chinese name: Lung Shuen Wan in the past and Leung Shuen Wan nowadays. Both names are believed to be derived from the fact that fishers used to bring food and water refills to trade ships moored in the bay with long watercraft that resembled dragon boats (lung shuen). Since the pronunciation of dragon (lung) and food (leung) sounds similar, the bay has been recorded as Leung Shuen Wan since 1730 (Rao 2012: 320-329).

During the regime of Jiajing Emperor (1522-1566), High Island was made one of the six naval bases, of which three were established in what is now Hong Kong waters, each with eight ships and 210 soldiers reporting to the Nantou Navy Command Office. In 1644, the Qing Dynasty took over the regime in China. Yet, the pro-Ming factions continued to attack the coast, prompting the imperial government to evacuate all citizens living within $50 \mathrm{li}$ (about 12 miles) of the coast in 1661. Their homes and lands were burned in a bid to stave out the rebels while all external trade by sea was banned. Upon the revoking of the Coastal Evacuation Order, many Hakka people (guests) moved to Hong Kong during that time. Since the fertile lands were occupied by Punti people (locals), Hakka people were forced to settle in less desirable lands like Sai Kung. This included the Chan clan, who settled in Yim Tin Chai near Kau Sai Island during the mid-18th century, which later became well-known for its salt-making (Wan 2004).

Riding on the rapid development of Sai Kung, High Island Bay became more prominent. Trading ships moored there and were subjected to tariff duties (Sai Kung District Council 2003). The area was also of high military importance because of its proximity to the Dapeng Fortress in Shenzhen, which administered the fort in Tung Lung Island in Sai Kung district. Town Island, High Island and Joss House Bay can also be found on various versions of the Haijiang Yangjie Xingshi Quantu 海疆洋界形勢全圖 (Coastal Map of China) first published in Hai Guo Jian Wen Lu 海國聞見錄 (Records of Sea Countries) written by navy commander Chen Lun Jiong in 1730 (as shown in Figure 4), which suggests the area was deemed an important navigational feature at a national level. 


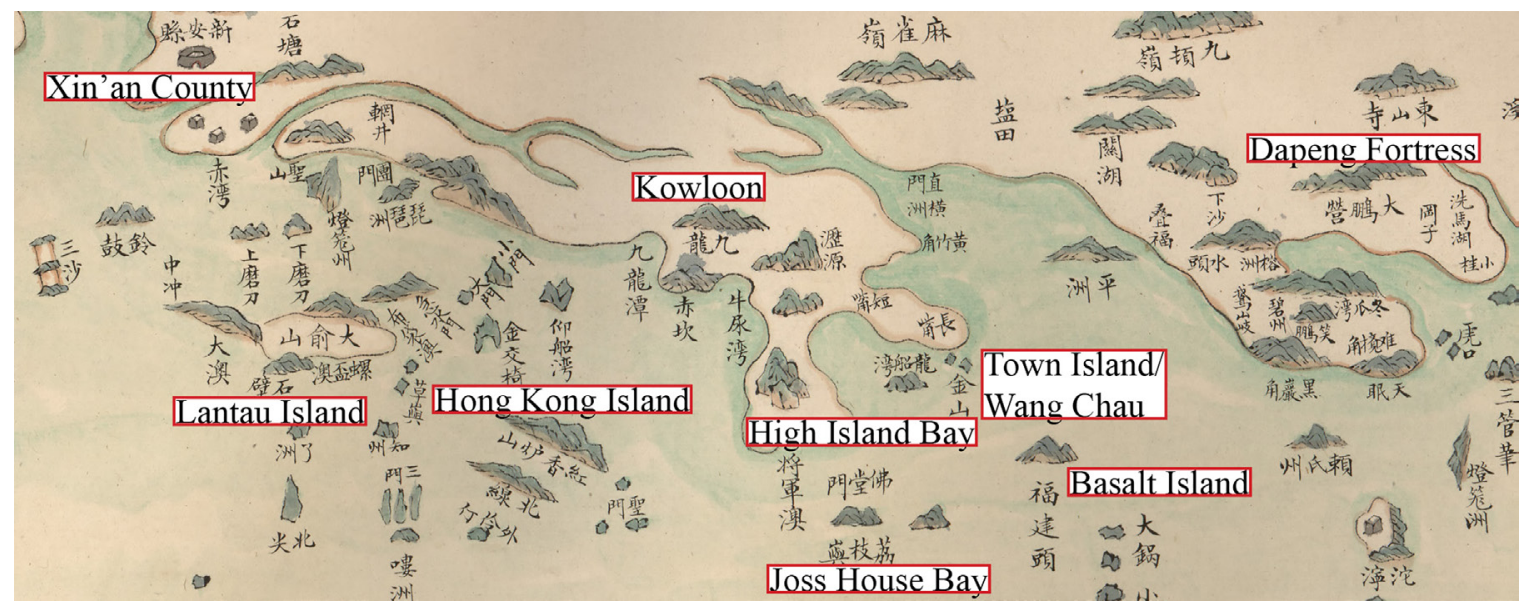

Figure 4: The area of Sai Kung shown in the Coastal map of China created between 1787 and 1801 (photo courtesy of Library of Congress, Geography and Map Division).

\section{BOAT DWELLERS AND FISHING}

An important human context about how people utilised the coast and sea in the Sai Kung district can be seen in the activities of Hong Kong's boat dwellers and fishers. From the 18th century, there were a substantial number of boat dwellers - also known as Tanka people who live solely on their boats and have no land dwellings - to be found in the Sai Kung district, and where fishing became an important source of cash income from the mid19th century. Leung Shuen Wan was most likely the first market centre for this area. Later Sai Kung established its own market for fishers to sell and barter fish. When fishing boats became mechanised, Sai Kung also developed important ship building and repair facilities (Faure 1982: 163-170). In a census of 1911, there were 394,941 land-dwellers and 61,798 boat dwellers, which made up to $15 \%$ of the total population in Hong Kong (Kani 1967: 16-17). In Sai Kung, there were 9,243 Punti and Hakka people, but the number of boat dwellers was unknown (Faure 1982: 173).

An interesting cultural practice unique to boat dwellers were the traditional folksongs they used in navigating these waters, called Salt Water Songs. In Yip's (1989) study on Folk Songs of Sai Kung in 1989, he recorded two versions. The first was given by Cheung Ming-hap, then head of Kwun Mun village, who learned the song from his father. It highlighted the landmarks and sailing conditions along the route from Daxing Mountain in Huidong County, $60 \mathrm{~km}$ east of Hong Kong, to Chiwan Village in Shenzhen. 
The verses concerning Town Island are as follows:

Fan Tsang Island [Conic Island] marks the entrance of Kwun Mun.

Drift to Po Pin Island when there is no wind.

Big Pak Lap, small Pak Lap;

sway the sail when there is no wind.

See Wong Nai Island on the side;

enter the Key Door ${ }^{1}$ [Town Island].

Then sail smoothly to Kwo Chau Islands [Ninepin Group].

Another fisher, So Yau-fuk, who used to fish between Shenzhen and Zhoushan Archipelago in Shanghai, gave an extended version of the same song, covering the route from Shantou on the eastern coast of Guangdong province to Chiwan Village in Shenzhen (Yip 1989: 156-158). It shows the extent of their activities.

The lyrics noted the fishing boats coming from Mirs Bay, and passing Conic Island to Kwun Mun, and then manually swaying the sail to move the boat between Pak Lap Bay and Wong Nai Island, before reaching the northern bay of Town Island (as shown in Figure 5). The Town Island bay investigated in the archaeological research and reported here, was highly likely to be used as a rest stop for many fishing boats awaiting favourable wind.

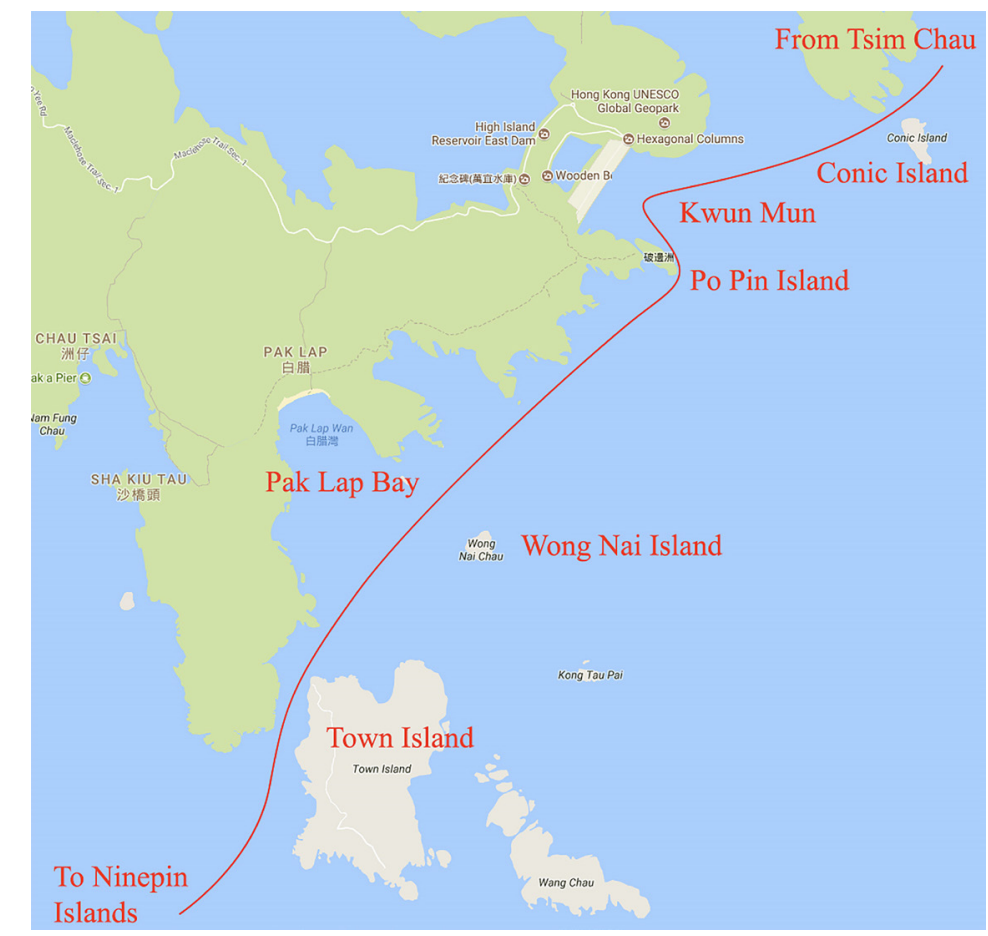

Figure 5: The route recorded in the fishers' folk song (drawn by Joyce Kam using Google Maps). 


\section{TOWN ISLAND MARITIME ARCHAEOLOGY PROJECT}

In 2009, the HKUHG implemented a project which included the development of a database of maritime archaeology sites in Hong Kong. Essentially a desk-top survey, the investigation produced a database of 282 sites from archival sources, and oral histories from Hong Kong people. Field work implemented as part of the project focused on the Sai Kung district given the potential to reveal significant UCH sites in context with coastal heritage sites, and the living heritage associated with the boat dwellers and fishers. One of the activities in this project was the survey and a sample recovery of artefacts from an area of seabed off Town Island, identified in 2010 (HKUHG 2015; Jeffery et al. 2013).

Town Island (or Fo Tau Fan Chau) is located $21 \mathrm{~km}$ east of Hong Kong island, and adjacent to Rocky Harbour (as shown in Figure 2). Roughly rectangular, Town Island measures $1 \mathrm{~km}$ from north to south and $0.5 \mathrm{~km}$ east to west. Its highest point is $73 \mathrm{~m}$ above sea level and much of its interior comprises undulating slopes, semi-wild shrub land and small woodlands (Stokes 2007: 158-159).

The underwater archaeological site became known following oral history research with a number of Hong Kong scuba divers. It is located in about 4 to $5 \mathrm{~m}$ of water, on a sandy-silty seabed, in the bay at the northern end of the island. This bay would provide good shelter to small and medium sized vessels (fishing vessels and coastal traders) when the wind is coming from the east, south and west. Historical and oral history research did not reveal any shipwrecks within $2 \mathrm{~km}$ of Town Island.

Following the archaeology potential of the Town Island site being revealed in 2010 (Jeffery et al. 2013), an intensive artefact recovery project was implemented for 15 days at the Town Island site in 2014, in which 20 Hong Kong and four international scuba divers participated. For one of the international divers, the site was a topic for his Flinders University Master's in Maritime Archaeology research (Russ 2014). A total of eight $10 \mathrm{~m} \times 20 \mathrm{~m}$ grids were laid out on the seabed to provide a framework for two-dimensional recording of each tagged artefact to be recovered. A total of 380 artefacts were recovered from the surface of the seabed; excavation was not employed, given budget and resource limitations. All the artefacts were transported back to the field base at Tung Sam Kei in Long Harbour under the care of Paul Harrison, a conservator from the HKMM. On completion of the field work, the artefacts were washed and further documented at the HKMM, and a report provided to the Antiquities Authority (Jeffery et al. 2016). 


\section{Town Island Artefacts}

The materials recovered off the northeast coast of Town Island represent a quite typical assemblage of late Qing food preparation, storage, and consumption wares, as are regularly found on contemporary terrestrial sites associated with rice-farming villages such as at Sha Po Tsuen on Lamma Island (Atha and Yip 2016). The vast majority of the Town Island ceramics are considered to be late Qing in date (19th to early 20th century), but there are also rather smaller quantities of mid-late Qing material (18th to 19th century), as well as 20th century material, including vessels post-dating the establishment of the People's Republic of China. Perhaps the most surprising finds were two qingbai glaze lobed bowl rims and a green glazed celadon rim, all dating somewhere within the period spanning the late 13th to early 17th century (Yuan-Ming) and made in Fujian.

The vast majority of the recovered artefacts were ceramics, followed by much smaller quantities of ceramic building materials and two small glass bottles. While two small sections of lamp glass were found, the site did not contain any other types of artefacts. The ceramics consist of (quantity in parenthesis): Historic Coarse Ware (3); Historic Sandy Fabric (28); Historic Stoneware (65); Porcelain or Proto-Porcelain Celadon (1); Provincial Porcelain (266); Porcelain or Proto-Porcelain Qingbai (6); SSW: Salt-Glazed Stoneware (3). The majority were the Provincial Porcelain (266), a fine white, grey or cream fabric, high fired, glassy glaze typically over blue and white or polychrome painted decorations - sometime plain white, the classic type being from the local Wun Yiu kiln, of which most are Qing in date. The second most common type was the Historic Stoneware (65), a range of hard, high-fired fabrics, some hand-made but mostly wheel-made, which are typically used for jar forms but also open forms such as basins, and can be slipped, glazed or plain in finish. Then there were Historic Sandy Fabric (28), a range of moderate to high fired sandy fabrics; these Qing examples were invariably wheel-made, often brown glazed lugged jars with upright hooked rims and basin forms, in particular foot-ringed unglazed rice grinding basins with flat, expanded rims (some with parallel grinding grooves, others with criss-crossed grooves).

The various functions of the ceramics include food preparation, storage and consumption wares. The consumption wares were almost entirely provincial porcelains and produced at Wun Yiu in Hong Kong and dated from the late Qing Dynasty (19th to 20th century). There were also a few wares from mid-late Qing (18th to 19th century). A number of 
underglaze blue bowls were produced in Fujian province, the bulk probably at the Dehua kilns, and lesser quantities most likely made at Jingdezhen in Jiangxi province, and at kilns in Guangdong province. These wares comprised bowls, cups, plates, dishes, spoons and teapots from the Qing Dynasty, 20th century, and Yuan-Ming Dynasties. The majority of the bowls were 12 to $13 \mathrm{~cm}$ in diameter and a much smaller number of 15 to $17 \mathrm{~cm}$ diameter. The larger bowls almost exclusively carried the "double happiness" design (as shown in Figure 6), whereas the smaller bowls - classic rice bowls or wun - carried a number of different designs, with the most popular being "floral-fungus", "plum, orchid, bamboo and stone", "ling chi" and "chrysanthemum" designs. While many of the smaller bowls are from Wun Yiu, only six out of 59 bowls of "floral-fungus" type were considered to be products of the Wun Yiu kilns, whereas the bulk were thought to come from the Dehua kilns. Moreover, the bulk of bowls of this type were angular in form and therefore late Qing in date.

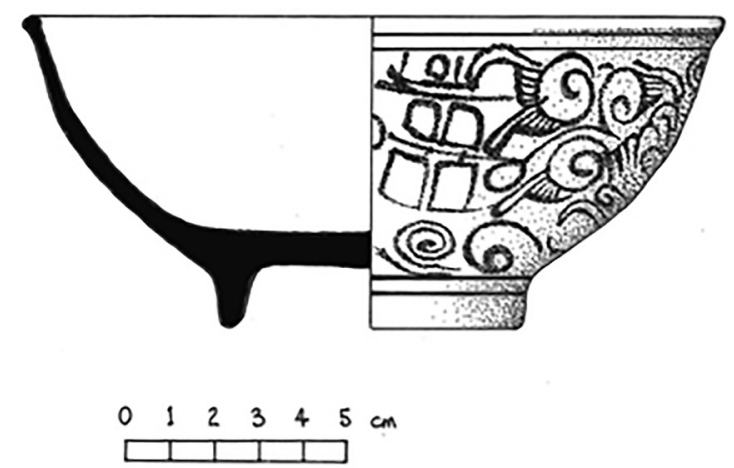

Figure 6: Bowl with underglaze blue double happiness design (drawn by Bill Jeffery).

The porcelain drinking vessels were sub-divided into cups $(6.5$ to $8.7 \mathrm{~cm}$ diameter) and small cups (4.0 to $4.7 \mathrm{~cm}$ diameter), mostly bearing a "petal, fungus, and cross" (as shown in Figure 7) or "floral-fungus" design. The majority were also Wun Yiu products, but a few better-quality examples were probably from Guangdong, Fujian or Jiangxi provinces. In terms of function, the cups would be used for drinking tea, and perhaps also rice wine, whereas the small cups were typically used for rice wine and kung fu tea, and probably also for ritual activities. Rice wine was also indicated by the presence of a qingbai glaze wine jar.

The number of Qing Dynasty porcelain plates and dishes was relatively small, but some interesting finds included late Qing plates from Wun Yiu (as shown in Figure 8) and Jiangxi, as well as an earlier Qing (17th to 18th century) plate from Jiangxi's Jingdezhen kilns. 


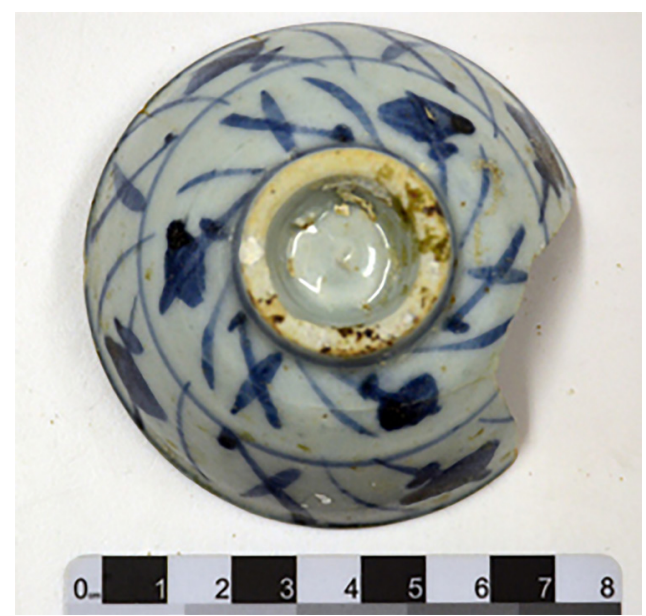

Figure 7: Cup with underglaze blue petal fungus and cross design, outside (photo by Bill Jeffery).

In the storage ware category, diagnostic rim and shoulder sherds of brown glazed storage jars were found, including four and eight-lugged storage jars. The form, fabric and glaze are all suggestive of Guangdong manufacture and a late Qing dynasty date, while continued use into the early 20th century is likely. Four shards of another type of storage jar were found including a thick-walled salt-glazed stoneware jar with vertical sides, angled shoulder and narrow upright neck. The fabric and glaze, which was darker brownish orange above the shoulder and paler yellowish brown below, suggest a European source, most likely English, and 19th century in date.

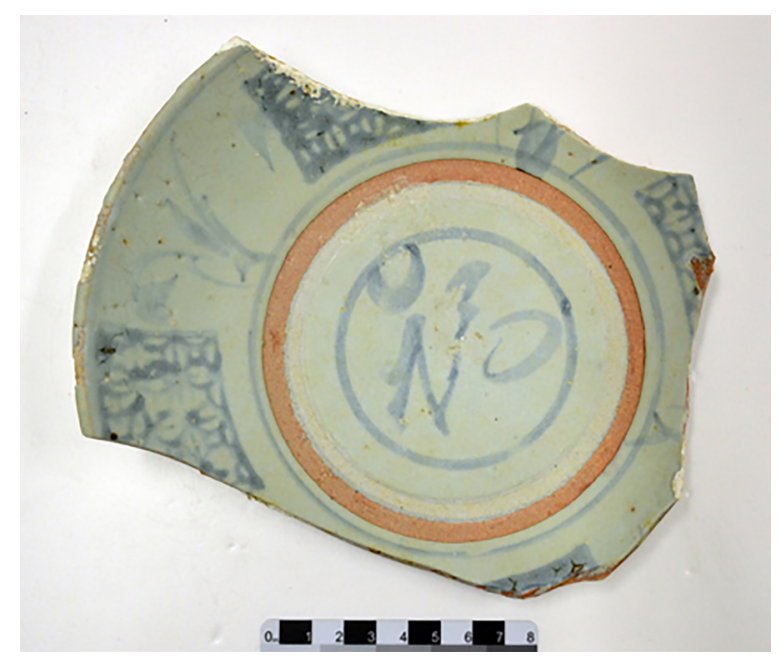

Figure 8: Plate with underglaze blue with rectangular block decoration, $F u$ symbol at inside centre base (photo by Bill Jeffery). 
The assemblage of food preparation wares comprised unglazed rice grinding basins, lid-seated wall-handled stoneware cooking pot and flat-bottomed carinated cooking-serving dishes with brown glazed rims and insides. Cooking was also evidenced by the recovery of the base of an earthenware charcoal stove, together with a fragment of perforated earthenware grate, similar to examples found at Sha Po Tsuen (Atha and Yip 2016) and Tung Lung Fort.

The later assemblage consisted entirely of porcelain, dominated by bowls in a variety of size and finishes, from plain white and pink to brown-and-white, and various underglaze polychrome designs applied by painting, but in some case using stencils or maybe stamps, and also transfer printing. Also present was a "studio type" 20th century plate with a striking bright blue fish design and a "peony" design dish from Jiangxi Jingdezhen (as shown in Figure 9).

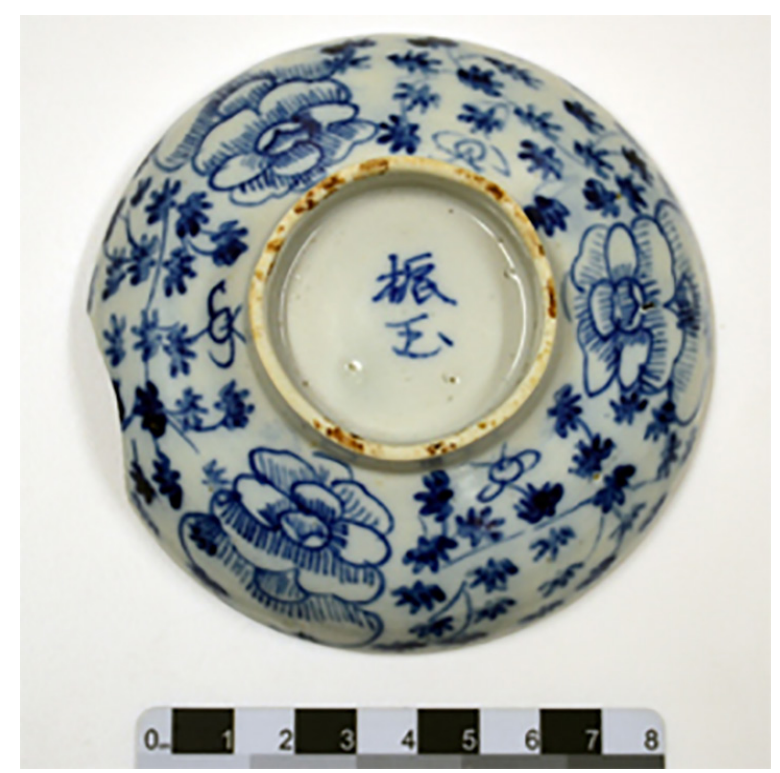

Figure 9: Plate with underglaze blue peony design, Chinese character $Y u$ (Jade) and Zhen mark at underside centre base (photoby Bill Jeffery).

\section{Discussion on Town Island Artefact Assemblage}

The pattern of ceramics consumption indicated by the Town Island assemblage is in general terms quite similar to that evidenced at 19th early 20th century terrestrial sites in Hong Kong, for example at Sha Po Tsuen, Lamma Island (Atha and Yip 2016). There is the same general range of storage, food preparation and consumption wares present, which indicates that the fishers and coastal traders making use of the Town Island anchorage 
had access to the same markets as land-based communities. Most of the storage and cooking wares were probably Guangdong products, widely available in local coastal markets, whereas the consumption wares evidenced a shift from a greater reliance on Wun Yiu products in mid-late Qing, towards an increasing emphasis on products of Fujian kilns by the later 19th and early 20th centuries, and then a growing reliance on cheaper, mass-produced ceramics from Fujian and, in particular, Jiangxi Jingdezhen during the interwar and post-World War II periods.

It can be inferred that the Hong Kong region's floating and landbased communities had similar foodways, perhaps not in the details of the specific ingredients and meals - there was presumably a far greater proportion of fish and other seafood in the diet of the floating population when compared to Sai Kung's rice farmers - but rather in terms of the materiality and modes of food preparation, serving and consumption.

Interestingly, there are 21 bowls that might be considered kiln "seconds," due in 18 cases to improper "green" firing resulting in an odd colouration and/or surface finish, and in three instances to vessel rims becoming deformed during firing. The fact that seconds were being bought and used by the community may be telling us something about their unequal relationship with traders in the coastal markets where ceramics were procured, and perhaps also their relatively low buying power and status.

The artefact assemblage also supports the use of the well protected bay as an anchorage for fishers and small trading vessels. There is no indication that the site is related to exporting ceramics, as the quantity of the ceramics does not fit this activity. They represent a quite typical assemblage of late Qing food preparation, storage and consumption wares, regularly found on contemporary terrestrial sites. Some of the same ceramic artefacts from the Wun Yiu, Jiangxi Jingdezhen and Dehua kilns found at the Town Island site have been found in local markets by one of the authors in Thailand as well as recovered from a shipwreck site in Sri Lanka.

The artefact assemblage provides an interesting insight into the lives of the boat-based communities who used the anchorage during a main period of deposition spanning perhaps 150 to 200 years. It is estimated that the latter deposition was around the mid-1900s when mechanised purse seiners had taken over from sailing vessels, and with larger coastal trading vessels they operated further offshore, resulting in little to no need for using the Town Island anchorage. The absence of more modern artefact materials supports this theory. Almost the entire range of ceramic material culture seems to be present: from food storage, processing and 
cooking to the consumption of food and drink. The Town Island assemblage therefore provides a very useful baseline data set for comparison with past and future materials recovered from sites relating not only to maritime focused communities, but also to those of their land-based contemporaries throughout Hong Kong.

The discovery of three much earlier sherds is tantalising and may indicate the use of the anchorage by earlier fishers, or more likely by smaller coastal trading vessels from an early period, which is consistent with the historical records. Coupled with the fact that all the artefacts were handcollected from the surface of the seabed, excavation has the potential to reveal a more complex appreciation of human activity along this section of the China coast, which can be traced back to the Yuan Dynasty, and possibly further.

Two other adjacent sites complement the dynamic nature of this region's maritime cultural landscape being revealed through maritime archaeology. As with the Town Island project, the following investigations were carried out under licence from the Antiquities Authority and a report compiled for the Antiquities Authority (Jeffery et al. 2018).

\section{HIGH ISLAND ANCHOR STOCK SITE}

In 2014, the team working at Town Island investigated a number of bays in the vicinity to check if they also contained any significant archaeological material. One of these areas consisted of a small cove at the southern tip of High Island, where a small amount of blue and white porcelain was observed, and what proved to be a stone stock for a Chinese timber anchor, located in about $4 \mathrm{~m}$ of water and within $10 \mathrm{~m}$ of the rocky coastline (as shown in Figure 2). No other cultural material such as that related to a shipwreck was observed. It is an unlikely location for anchoring a vessel given its proximity to the coastline and rocky seabed.

The stock, made of shaped granite, is $1.64 \mathrm{~m}$ in length, $0.21 \mathrm{~m}$ at its largest breadth measurement, and $0.12 \mathrm{~m}$ at its largest depth measurement (as shown in Figure 10). The stock was a removable part of a distinctly Chinese anchor, allowing both the main part of the anchor and the stock to be stowed separately and flat on the deck of a vessel. There are two depressions midway along the length of granite showing where it was fitted into the timber stem of the anchor. The rest of the anchor would have been made of timber, with perhaps some iron fittings. 
Needham (1987: 658) reported that the "Chinese adze anchor" can be traced from the 17th century back to the 2,000 year-old Cantonese tombmodel ship. The Cantonese tomb-model ship refers to the pottery boat from the Han Dynasty (25 to $220 \mathrm{CE}$ ) and unearthed in Eastern Guangzhou in 1955. Similar shaped stone anchor stocks have been observed by one of the authors at the Guangdong Maritime Silk Road Museum located in Yangjiang, China, and at the Museum of Overseas Communication History in Quanzhou, China. Both stone anchor stocks were about $2.3 \mathrm{~m}$ in length, and from ships of the Song Dynasty (960-1279) (Green 1983; Green et al. 1998) (as shown in Figure 11). A similar, but more rudimentary stone stock was observed by one of the authors on a timber anchor from a Yuan Dynasty (1279-1368) ship, which is on display at the Kyushu National Museum in Japan. It was recovered from one of the invading Chinese ships in the mid to late 13 th century.

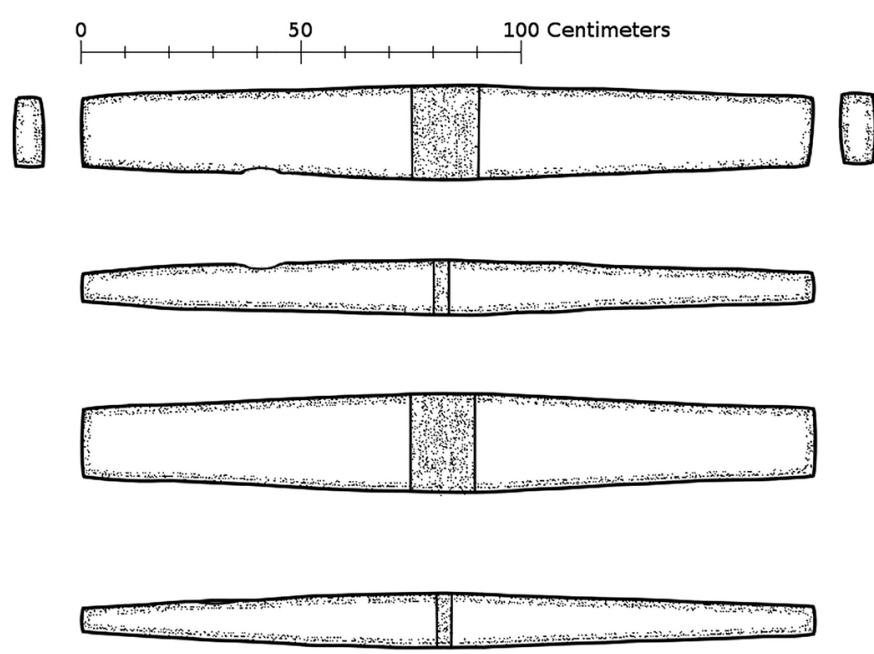

Figure 10: The stone anchor stock (drawn by Guilhem Malfre, assisted by Jamie Yeung, 2016).

The porcelain that was found is not contemporary with the stock as it is similar to the mid to late Qing wares from the Town Island site. There are a number of scenarios as to why this site contains a Song Dynasty anchor stock, and later Qing porcelain. Similar small amounts of porcelain were observed in a number of places in the general area, including in a number of bays throughout Hong Kong, and indicate the high volume of Qing Dynasty fishers and traders in these waters.

The anchor stock is a rare and significant artefact for Hong Kong, the oldest ship remains so far found in Hong Kong waters. It is located along a well-travelled route for vessels, but why is it found on its own? There 
could be a number of reasons, but the fact the site does not contain any other shipwreck material, would suggest it is not a shipwreck site but a site where an anchor was either dropped or dragged to, and where the timber sections of the anchor had totally deteriorated. What can also be inferred from the stock? While it is identical to those in Yangjiang and Quanzhou, it is significantly smaller. It could possibly infer that the vessel was also smaller, or it was one of the smaller anchors used on the vessel, given a number of anchors of various sizes would be carried. The anchor stock is on display at the HKMM in the exhibition, "Where East meets West: Underwater Archaeology and the Ancient Maritime Trade."

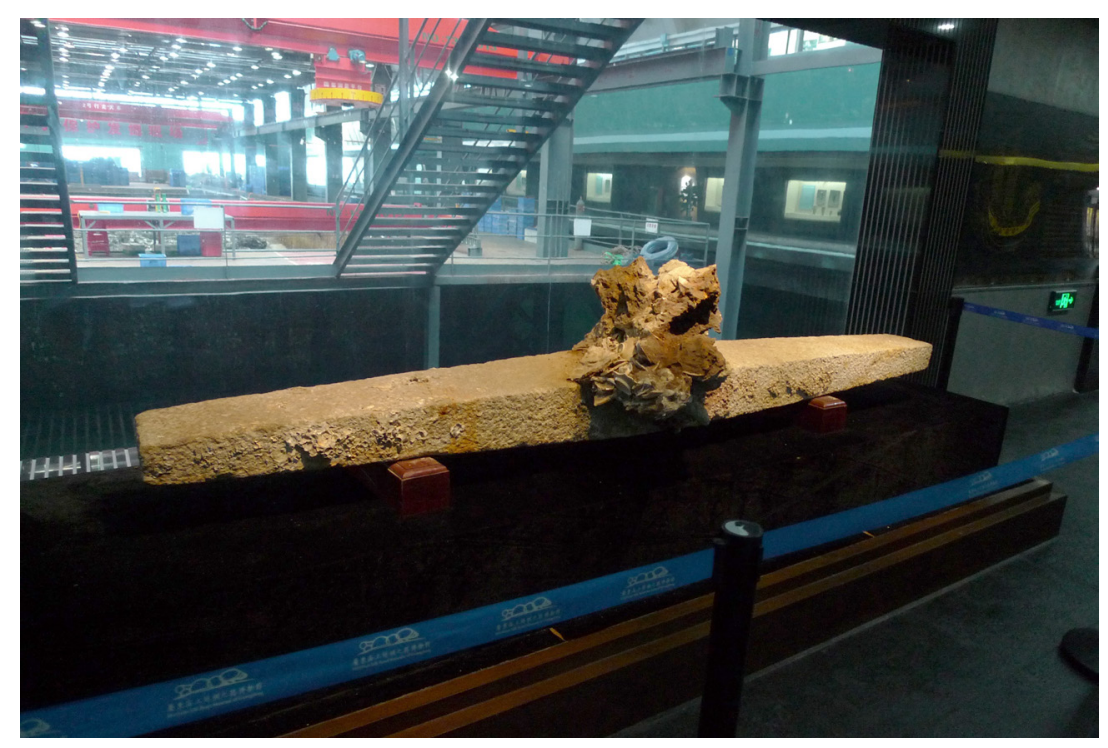

Figure 11: Stone anchor stock at the Guangdong Maritime Silk Road Museum, Yangjiang, China (photo by Bill Jeffery, 2011).

\section{BASALT ISLAND CANNON SITE}

Offshore from another adjacent island, Basalt Island, two 19th century cannon were found by a local scuba diver, Raymond Man. Located in about $14 \mathrm{~m}$ of water, the cannon lay on a ledge about $8 \mathrm{~m}$ above the silty seabed (as shown in Figure 2). Both iron cannon were encased in concretion and therefore no marks could be seen to identify their nationality or size. The concretion showed signs of cracking and corrosion. A survey on the cannon was considered to see if they were associated with a shipwreck, or if they could be recovered for the investigation of their origin, and to better care for them. Through the experience of Paul Harrison, the HKMM were in a position to conserve the cannon and facilitate the research. 
A survey of the surrounding area was carried out in mid-July 2016, and again in June 2017. No other cultural material, such as shipwreck remains or ceramics were found. Both cannon were recovered using lift bags, then picked-up by a small commercial crane boat and transported back to Kowloon, from where they were moved onto the HKMM.

The larger cannon is $1.93 \mathrm{~m}$ in length and contains the letters "ELC" and a crown above the letters, placed on the top of the barrel near the trunnions (as shown in Figure 12). It also appears to contain a concreted cannon lock and firing lanyard (to be confirmed), a device which came into service with the English Navy from 1790 (Mehl 2002: 116) (as shown in Figure 13). The second smaller cannon is $1.33 \mathrm{~m}$ and unmarked, but of the same style as the larger one. They are both muzzle loading cannon, i.e. powder and shot (cannon ball) loaded from the forward, open end of the barrel. The larger cannon bore is $11 \mathrm{~cm}$ in diameter and therefore is a nine-pounder, the smaller cannon is $8 \mathrm{~cm}$, and is a four-pounder. They were made to be used on a carriage in ships, as seen by the trunnions, and the restraining ring, which was a feature Thomas Bloomfield (Inspector of Artillery in England) added after 1787 (Collins n.d.). The Guangzhou Museum (Zhenhai Tower) has a similar cannon with the same marks "ELC" and a crown in the same location on the barrel, labelling it as British.

How did they end up at the back of Basalt Island? A number of 18th and 19th century cannon have been recovered from Hong Kong waters, although not found in association with a shipwreck, and therefore considered as dumped. While the Basalt Island cannon were most likely British made, they could have been used any number of vessels. Piracy was rampant in Hong Kong for hundreds of years and many of their vessels carried cannon. G.W. Cooke, a Times correspondent travelling throughout China from 1857 to 1858, covered the trial of an American Eli Boggs for murder and piracy in Hong Kong in 1857, and wrote of a general scene he witnessed,

Where I now write there are 200 junks lying in the harbour before me, and every one of them is armed with at least two heavy guns [cannon] - some have twelve. Probably one quarter of these are pirates, who live principally by piracy, and adopt the coasting trade only as a cover to their real profession. (Cooke 1858: 69)

At the beginning of the 20th century, the Hong Kong government passed a law, the Arms and Ammunition Ordinance, 1900 (No.2 of 1900), requiring a master or an owner of a vessel to have a license to carry aboard arms or 
ammunition (including cannon), and which remained in the 1933 and 1981 versions of the law, and seen on Hong Kong's legislation website for Cap. 238, Firearms and Ammunitions Ordinance, 1981. In a Life magazine article of 1949, the photograph on the cover is of a Chinese Junk (reported to be one of many) sailing in Macau/Hong Kong waters as part of an illicit trade in gold. The caption for the photograph is: "A 'fishing' junk armed with five old cannon (one visible between the masts, another near stern) leaves Macao Harbour with patchwork sails high" (Life 1949: 19).

The earliest date for the manufacture of the two Basalt Island cannon appears to be about 1790, and the date for their deposition at Basalt Island could be any date between then and the mid-20th century or even later. As the cannon do not appear to be connected to a shipwreck, and their location is not conducive to them being used as a mooring, they may have been dumped as is suggested in the cannon page of the US National Park Service website for the Castillo de San Marcos National Monument in Florida, dated 14 th April 2015:

As the casting process was perfected iron cannon became more numerous; iron guns were generally lighter and cheaper but offered the same amount of strength [as a bronze cannon]. Iron did have a drawback however, it crystallized overtime and became more brittle, thus iron pieces wore out quicker and could not be melted down and recast like bronze. At the end of their life-span iron guns were simply abandoned [emphasis by the authors].
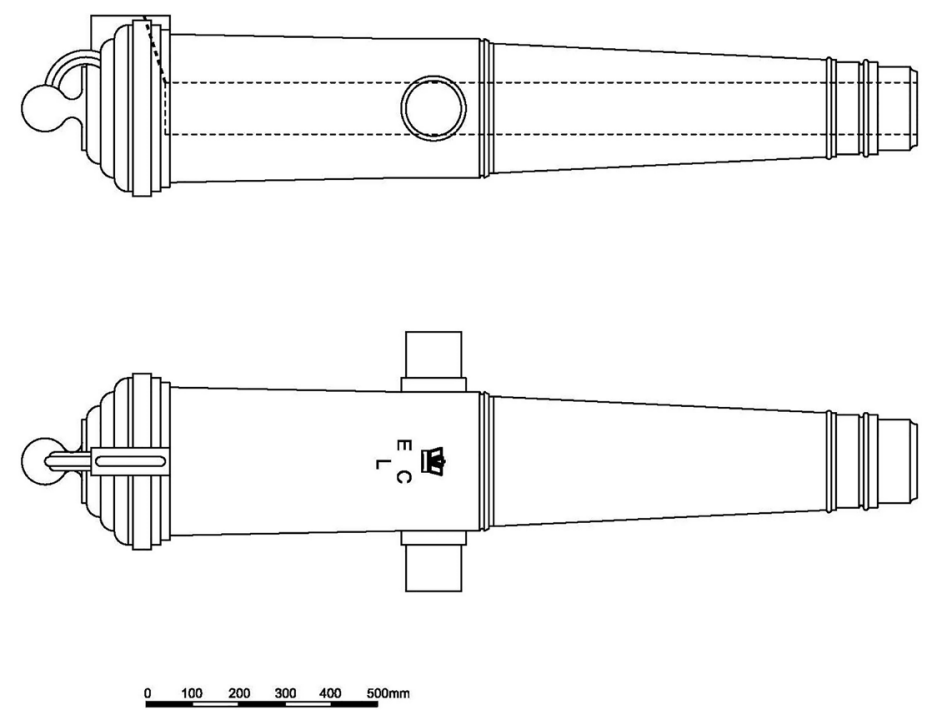

Figure 12: The larger iron cannon showing the marks "ELC" between the trunnions (drawn by Rick Chan). 


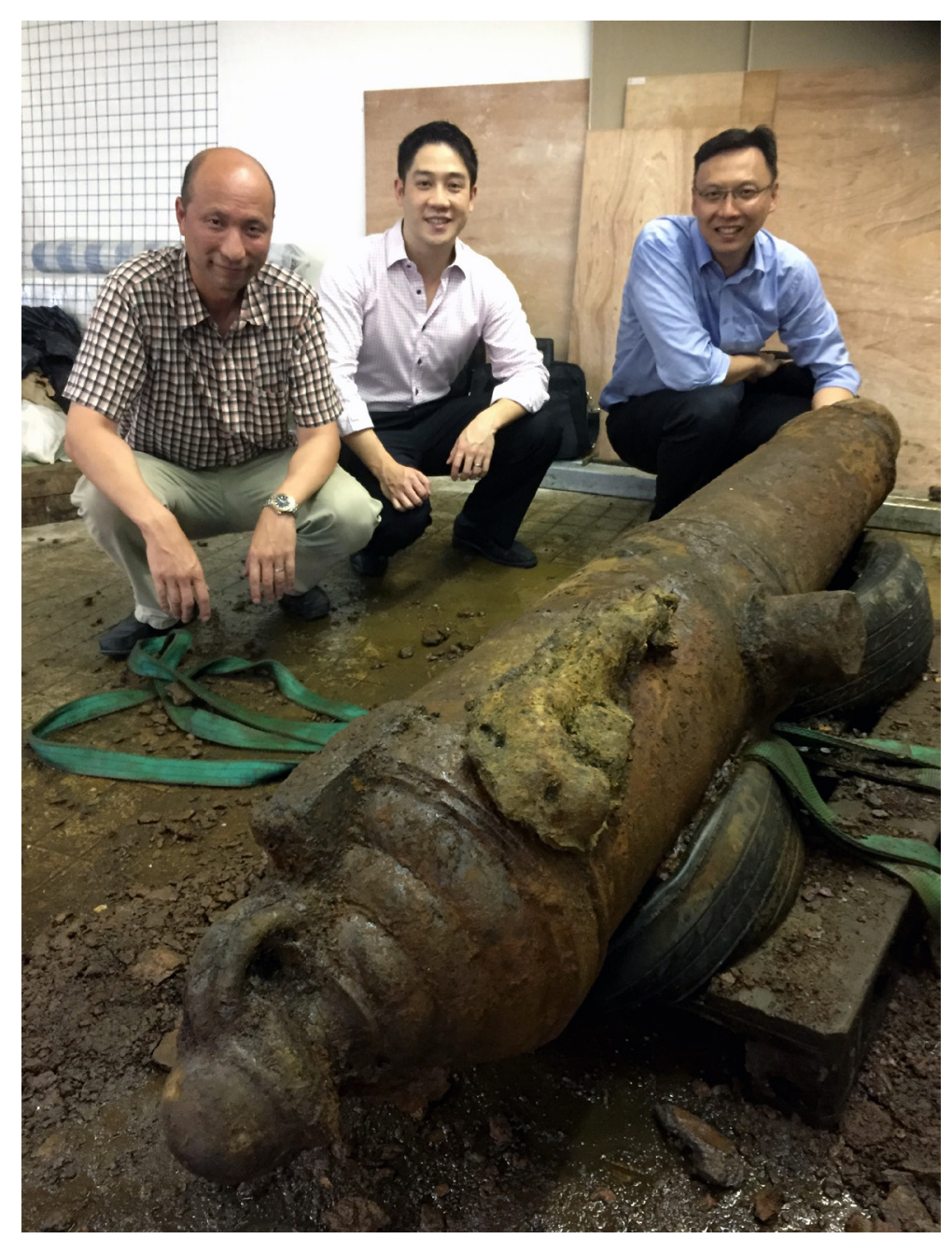

Figure 13: The larger iron cannon with what looks a concreted lanyard, accompanied by members of HKUHG (left to right): Rick Chan, Terence Chu and Marco Li (photo by Bill Jeffery, 2016).

\section{CONCLUSION}

The Sai Kung district of Hong Kong has an extensive and significant maritime cultural landscape that can be seen in the many tangible cultural heritage sites, such as UCH sites, rock carvings, temples, ports, markets, forts, the living heritage encompassing the Tin Hau ceremonies, and the cultural practices of Hong Kong's boat dwellers and fishers. Research into the UCH sites revealed in this paper illuminate a maritime cultural landscape that is indicative of what has existed in many parts of Hong Kong, but has now largely disappeared through coastal reclamation and development. The Town Island ceramics provide connections with production centres in the Sai Kung district, as well as from Guangdong, Fujian and Jiangxi provinces 
in China, and from England. The artefacts offer a glimpse into the lives of boat dwellers, how they lived aboard their vessels while fishing and trading along the Sai Kung coastline and adjacent waters. Together with the anchor stock and cannon, this cultural heritage is made up of authentic material remains, and provides a chronology on who was using the landscape and seascape, with some interesting dilemmas. The anchor stock is for a Chinese vessel, but where was it going and what was its role, and who used the British cannon and when? The Sai Kung maritime cultural landscape is encapsulated in the Salt Water Songs, which were used to identify key features to help navigate along the coastline under different weather conditions.

Much of the archaeology that can supplement this cultural landscape in the Hong Kong region has been implemented at coastal sites, although this has included little maritime archaeology. Given that the extent of sea level rise in Hong Kong has been about 140 m until 6000 Before Present (BP), many prehistoric sites will be located underwater. While a handful of UCH sites have been discovered, several recent site discoveries and the implementation of projects have revealed Sai Kung's maritime cultural landscape and the significance of these sites. Generally, the work of HKUHG and the HKMM has been implemented in a piece-meal basis, and there are other important historic sites and themes that may be worthy of investigation, including the scene of the pirate battle at Chek Lap Kok/ Tung Chung; the location of the first China/Portuguese encounter at Tuen Mun; and Joss House Bay, the location of Hong Kong's oldest Tin Hau temple; and World War II, for example. A way forward should be a strategic one, where a holistic understanding of Hong Kong's maritime and $\mathrm{UCH}$ is developed, through a comprehensive assessment of its surviving maritime cultural landscape. This would facilitate an evaluation of the many maritime-related historic themes, site significance, and issues such as the suitability and feasibility of which sites, in addition to the living heritage, should be investigated. It has been shown the Hong Kong community, through HKUHG, and the many divers who have participated in training programmes and projects, that there is considerable public interest and merit in pursuing this activity. With a reported 70,000 scuba divers in Hong Kong, there are many potential volunteers from the community to be engaged. Maritime archaeology activities in Hong Kong are also consistent with, and supportive of, the very active maritime archaeology programme that is implemented in the People's Republic of China, and in particular the research and management activities associated with the Maritime Silk Road. 


\section{ACKNOWLEDGEMENTS}

We acknowledge the contribution from Sarah Heaver from 1998 in raising the potential of maritime archaeology in Hong Kong. The impetus for the maritime archaeology projects came from the establishment in 2009 of the HKUHG by Tammy Sau-man Chan, Rick Kei-yip Chan, Grace Sin-man Chow, Lydia Wing-chi Ho, Marco Li-hen Li, Peggy Pui-kee Wong and Bill Jeffery. Many others joined, primarily as a result of the UK Nautical Archaeology Society training programmes that were implemented in Hong Kong on at least seven occasions from 2009 to 2017. We would like to thank Mick Atha, $\mathrm{PhD}$, who compiled the Town Island artefact documentation and analysis that appear in this article, and together with Kennis Yip, facilitated an artefact drawing training programme for volunteers and students. Invaluable assistance came from Paul Harrison, the conservator at the HKMM, who took on the role of treating all of the artefacts mentioned in this article. Richard Wesley, former Director of the HKMM has been a great support in these projects, as well as generally in pursuing the need for maritime archaeology to be carried out in Hong Kong. Finally, the projects were supported by grants from the Lord Wilson Heritage Trust in 2009 and 2013, as well as financial contributions from the HKMM, the Environmental Resources Management (ERM) Foundation, and the CIE-Centre for International Heritage Activities. We would like to thank K.L. Tam, Richard Wesley, and the anonymous reviewers for their comments on this article.

\section{NOTES}

* Bill Jeffery is an Associate Professor, Anthropology, University of Guam and holds a PhD from James Cook University, Townsville, Australia. His primary interest is maritime archaeology, which he commenced in Australia before going on to work with the Federated States of Micronesia National Historic Preservation Office, and in Hong Kong. His interests are in researching traditional indigenous material culture and living heritage particularly in Oceania, revealing multi-vocality perspectives of underwater cultural heritage, developing community maritime archaeology, and highlighting how maritime cultural landscapes can reflect maritime cultural identities.

** Joyce Ho-ching Kam is a $\mathrm{PhD}$ student at the University of Hamburg reading history of Southeast Asia. Her research focuses on the maritime cultural landscape between Central Thailand and Southern China in the 17th to 19th centuries. A member of the 
HKUHG, she participated in maritime archaeological projects in Sai Kung. She then remains active in divulging the maritime history of her hometown.

1 Town Island was called "key door" in the song as it is the key to Kwun Mun, the "official door".

\section{REFERENCES}

AMO (Antiquities and Monuments Office). 2004. A brief outline on underwater archaeology in Hong Kong. Heritage Hong Kong: Newsletter of the Antiquities and Monuments Office, July 2004. https://www.amo.gov.hk/form/newsletter_200407 .pdf (accessed 21 December 2020).

. 2012. List of sites of archaeological interest in Hong Kong. https://www.amo .gov.hk/form/list_archaeolog_site_eng.pdf (accessed 1 July 2020).

Atha, M. and Yip, K. 2016. Piecing together Sha Po: Archaeological investigations and landscape reconstruction. Hong Kong: Hong Kong University Press.

Chan, A. T. -K. 2006. Parade for the queen: Safeguarding the intangible heritage of the Tin Hau sea ritual in Leung Shuen Wan, Sai Kung. MSc diss., University of Hong Kong, Hong Kong. https://doi.org/10.5353/th_b4218269 (accessed 4 April 2020).

China Daily. 2007. Exploration of the Nanhai No.1, 22 December. https://www.chinadaily .com.cn/china/2007-12/22/content_6341437.htm (accessed 29 December 2020).

Collins, A. R. n.d. British cannon design 1600-1800. https://www.arc.id.au/Cannon.html (accessed 21 December 2020).

Cooke, G. W. 1858. China: "The Times" special correspondence from China in the years 1857-1858. London: Routledge.

Draper-Ali, S. 1998. Potential for maritime archaeology in the Hong Kong SAR: Survey, assessment, management and conservation of the underwater heritage. Hong Kong: Lord Wilson Heritage Trust.

Faure, D. 1982. Saikung, the making of the district and its experience during World War II. Journal of the Hong Kong Brach of the Royal Asiatic Society 22: 161-211.

Frost, R. J. 1974. Sha Tsui, high island, part 1. Journal of the Hong Kong Archaeological Society 5: 23-27.

Green, J. 1983. The Song Dynasty shipwreck at Quanzhou, Fujian Province, People's Republic of China. International Journal of Nautical Archaeology and Underwater Exploration 12 (3): 253-261.

Green, J., Burningham, N. and Museum of Overseas Communication History. 1998. The ship from Quanzhou, Fujian Province, People's Republic of China. International Journal of Nautical Archaeology and Underwater Exploration 27 (4): 277-301.

Guo, F. 1595. Yue da ji [General record of Guangdong]. Wanli edition, reprinted in 1998. Guangzhou: Zhongshan University Press.

Hase, P. 2003. The historical heritage of Ho Chung, Pak Kong, and Shak Kok Mei, Sai Kung. Hong Kong: S.Y. Consultancy Service Co. Ltd. http://www.epd.gov.hk/eia/ register/report/eiareport/eia_1012004/eia_report/pdf/Volume\%201/app_10.4.PDF (accessed 21 December 2020). 
Heaver, S., Atha, M. and Harrison, P. 2015. Preliminary archaeological impact assessment of Wan Chai development, Phase II. Hong Kong: Report for the Civil Engineering and Development Department.

HKUHG (Hong Kong Underwater Heritage Group). 2015. Treasures of the deep: Surveying and documenting the underwater heritage of Hong Kong. Hong Kong: Hong Kong Maritime Museum. http:/www.hkuhgroup.com/cms/images/ Documents/treasures_of the_deep.pdf (accessed 22 December 2020).

Ho, C. -H. and Ng, B. 1974. Sha Tsui, high island, part 2. Journal of the Hong Kong Archaeological Society 5: 28-33.

Jeffery, B. et al. 2013. Recording and documenting the underwater cultural heritage of Hong Kong, Stage 1: A community maritime archaeology project. International Journal of Nautical Archaeology 42 (2): 412-419.

Jeffery, W., Kam, J. H. -C. and Atha, M. 2016. Town Island underwater archaeology project. https://www.lordwilson-heritagetrust.org.hk/filemanager/archive/project doc/10-155-2/Final\%20TI\%20Report\%20for\%20LWHT_Dr\%20William\%20 JEFFERY.pdf

Jeffery, W. et al. 2018. Maritime archaeological survey and excavation of an anchor stock on the southern tip of High Island and a Basalt Island cannon site. Unpublished report, Antiquities and Monuments Office, Hong Kong.

Kani, H. 1967. A general survey of the boat people in Hong Kong. Hong Kong: Chinese University of Hong Kong.

Lam, P. Y. -K. 1992. Ceramic finds of the Ming period from Penny's Bay-An addendum. Journal of the Hong Kong Archaeology Society XIII (1989-1992): 79-90.

Life. 1949. Macao: A dreamy old colony whose smugglers ply the China coast flourishes as richest traffic center of world gold trade, 27 (6): 19-23. 8 August 1949. https://books.google.de/books?id=y04EAAAAMBAJ\&lpg=PA19\&pg=PA19\#v $=$ onepage $\& \mathrm{q} \& \mathrm{f}=$ false $($ accessed 29 December 2020).

Lu, T. L. -D. 2007. Report on the date of the Wong Tei Tung Archaeological Assemblage. Department of Anthropology, The Chinese University of Hong Kong, 30 April. http://www.amo.gov.hk/form/Report\%20on\%20the\%20Date\%20of\%20the \%20 Wong\%20Tei\%20Tung\%20Archaeological\%20Assemblage.pdf (accessed 22 December 2020).

Meacham, W. 2008. The archaeology in Hong Kong. Hong Kong: Hong Kong University Press.

Mehl, H. 2002. Naval guns, 500 years of ship and coastal artillery. London: Chatham Publishing.

Needham, J. 1987. Science and civilisation in China. Volume 4, Physics and physical technology, Part III: Civil engineering and nautics. Cambridge: Cambridge University Press.

Prott, L. V., ed. 2006. Finishing the interrupted voyage: Papers of the UNESCCO AsiaPacific Workshop on the 2001 Convention on the Protection of the Underwater Cultural Heritage. United Kingdom: Institute of Art and Law.

Rao, J. 2012. Xianggang di diming yu difang lishi (xia): Xinjie [Place names and local history in Hong Kong (II): New territories]. Hong Kong: Cosmos Books. 
Russ, J. 2014. Maritime archaeology in Hong Kong: A study on the management of the underwater cultural heritage. MA diss., Flinders University, Australia.

Sai Kung District Council. 2003. Xigong lishi yu fengwu [History and cultural heritage in Sai Kung]. Hong Kong: Sai Kung District Council.

Stokes, E. 2007. Sai Kung islands. Hong Kong: Friends of the Country Parks.

Wan, J. C. -T. 2004. From salt pan to resort plan: Heritage conservation for the Island of Yim Tin Tsai, Sai Kung. MSc diss., The University of Hong Kong, Hong Kong. https://hub.hku.hk/handle/10722/40003 (accessed 29 December 2020).

Ward, B. 1985. Kau Sai, an unfinished manuscript. Journal of the Royal Asiatic Society of Hong Kong Branch 25: 27-118.

Westerdahl, C. 1992. The maritime cultural landscape. The International Journal of Mautical Archaeology 21(1): 5-14.

Wong, S. W. -Y. 2015. Southeast Asian ceramics found in Penny's Bay, Hong Kong: Importing evidence of exchange between China and Southeast Asia. Southeast Asian Ceramics Museum Newsletter 8 (2): 1-4. http://museum.bu.ac.th/Newsletter/ SEACM_V8_no2.pdf (accessed 21 December 2020).

Yip, K. C. -K. 1989. A study on the folk songs of Sai Kung and its neighbouring areas. M.A. thesis, Chinese University of Hong Kong, Hong Kong.

Zhang, S., and Ng, S. W. -H., eds. 2010. 2006 The important discovery of Hong Kong archaeology: Wong Tei Tung Paleolithic age site. Hong Kong: China Review Academic Publishers. 